Revista de la red interuniversitaria de estudios sobre las literaturas rioplatenses contemporáneas en Francia

$14 \mid 2016$

Levrero

\title{
Secretos del test extraterrestre
}

\section{Profesor Hybris}

URL: http://journals.openedition.org/lirico/2320

DOI: $10.4000 /$ lirico.2320

ISSN: 2262-8339

Editor

Réseau interuniversitaire d'étude des littératures contemporaines du Río de la Plata

Referencia electrónica

Profesor Hybris, « Secretos del test extraterrestre », Cuadernos LIRICO [En línea], 14 | 2016, Puesto en línea el 07 junio 2016, consultado el 19 abril 2019. URL : http://journals.openedition.org/lirico/2320 ; DOI : $10.4000 /$ lirico. 2320

Este documento fue generado automáticamente el 19 abril 2019.

\section{(c) $(1) \Theta \Theta$}

Cuadernos LIRICO está distribuido bajo una Licencia Creative Commons Atribución-NoComercialSinDerivar 4.0 Internacional. 


\title{
Secretos del test extraterrestre
}

\author{
Profesor Hybris
}

Por el parasicólogo y astrólogo Profesor Hybris

1 La prensa mundial ha revelado recientemente los detalles del extraño caso de Asdrúbal Carrasquilla, el camionero chileno que desapareciera misteriosamente en su país, ante el asombro de varios automovilistas que lo vieron desvanecerse en el aire, junto con su camión, en la muy transitada vía entre Las Fraguas y San Venancio, en la provincia chilena de Valverde. El hecho ocurrió a las 16.55 del 15 de diciembre de 1981. A las 16.58 del mismo día, según confirman varios testigos presenciales, se le encontró desvanecido en una calle en pleno centro de la ciudad de México. Trasladado a un centro de asistencia, recobró rápidamente el conocimiento y los médicos pudieron dictaminar un excelente estado de salud, física y mental. Entre sus ropas se encontró su documentación chilena perfectamente en regla, y un extraño documento, semejante a un librillo de pocas páginas, impreso sobre una sustancia parecida al papel pero que resistió todos los análisis de laboratorio. El extraño lenguaje pudo ser interpretado gracias a las claves que proporcionara el propio Carrasquilla, quien afirmó haber sido raptado por seres extraterrestres en una nave espacial invisible. El misterio tal vez más inexplicable de todos sea la curiosa distorsión del tiempo, pues Carrasquilla asegura haber pasado varias días en el interior de la nave, mientras era sometido a una serie de análisis y recibía al mismo tiempo ciertas enseñanzas por parte de seres extraterrestres de forma humana. Su camión, a todo esto, fue detectado como un objeto extraño que flotaba sobre las aguas oceánicas próximas a Centroamérica, y puesta en alerta la Fuerza Aérea Norteamericana un helicóptero siguió su rastro hasta comprobar su desaparición en la zona conocida como "Triángulo de las Bermudas". En cuanto al librito encontrado en poder de Carrasquilla, la traducción reveló que se trataba nada más ni nada menos que de un test.

2 Si usted ha leído hasta aquí, haya o no creído en lo que venimos diciendo, le pido disculpas. He mentido descaradamente. Mi hombre no es Hybris (palabra que en griego significa algo así como "pecado de exceso"), ni soy parapsicólogo, ni profesor de nada; apenas un periodista que, como muchos otros, se gana la vida como puede -a veces poniendo a prueba la credulidad del lector. 
3 Si usted me creyó, totalmente o a medias, esta especie de test da como resultado que usted tiene un exagerado respeto por la letra impresa. Si no me creyó, cosa muy comprensible, el resultado de su test le dice que no es conveniente burlarse de todo lo que suena a disparate sin un mínimo de previa investigación; existen otros hechos inexplicables que, sin embargo, son auténticos.

4 Como dato complementario debo agregar que los nombres son inventados. Incluso los de las regiones chilenas que, si alguien llega a encontrarlos en un mapa, será por pura coincidencia.

Privada $\mathrm{N}^{\circ}$ 1, abril 1982 